DOI: 10.18276/sip.2018.54/3-05

\title{
Beata Bieszk-Stolorz*
}

Uniwersytet Szczeciński

\section{WYKORZYSTANIE TESTU GRAYA DO OCENY WPŁYWU PŁCI NA FORMĘ WYJŚCIA Z BEZROBOCIA}

\section{Streszczenie}

Celem artykułu jest ocena wpływu płci na prawdopodobieństwo wyrejestrowania z urzędu pracy z powodu podjęcia pracy niesubsydiowanej, pracy subsydiowanej, podjęcia działalności gospodarczej, wyjazdu za granicę, przejścia na rentę, emeryturę lub zasiłek i pozostałych przyczyn. Te formy wyjścia z bezrobocia stanowią różnego rodzaju zdarzenia konkurujące. W badaniu wykorzystano metody analizy trwania uwzględniające występowanie obserwacji cenzurowanych. Do oceny ryzyka zdarzeń konkurujących zastosowano funkcję skumulowanej częstości $(C I F)$. Pozwoliła ona na ocenę prawdopodobieństwa formy wyjścia z bezrobocia.W celu zbadania różnic we wpływie płci na prawdopodobieństwo wyrejestrowania z powodu określonej przyczyny zastosowano test Graya. Analizowano je w podgrupach wyodrębnionych ze względu na cechy osób bezrobotnych: wykształcenie, wiek, liczbę zarejestrowań i staż pracy. W badaniu skorzystano z danych indywidualnych osób zarejestrowanych w Powiatowym Urzędzie Pracy w Szczecinie.

Słowa kluczowe: analiza trwania, funkcja skumulowanej częstości, test Graya, bezrobocie, płeć

\section{Wstęp}

Różnice w sytuacji kobiet i mężczyzn na rynku pracy są przedmiotem wielu badań i raportów (Kotowska, 2009; Bieszk-Stolorz, Markowicz, 2013; Matuszewska-

* Adres e-mail: beatus@wneiz.pl. 
-Janica, Hozer-Koćmiel, 2015). O trudniejszej pozycji kobiet w tym obszarze świadczą: niższy współczynnik aktywności zawodowej, niższy wskaźnik zatrudnienia, wyższy poziom bezrobocia, brak równości w wynagrodzeniach, mała obecność kobiet na wyższych stanowiskach i w zarządach firm. Zmiany współczesnego rynku pracy i przemiany kulturowe zachodzące w ostatnich latach wpływają na stopniową zmianę tej sytuacji. Do pozytywnych czynników należy upowszechnianie elastycznych form zatrudnienia, wzrost wykształcenia kobiet i odchodzenie od tradycyjnego modelu rodziny na rzecz modelu partnerskiego.Według danych BAEL w IV kwartale 2016 roku stopa bezrobocia kobiet $(5,7 \%)$ była wyższa niż stopa bezrobocia mężczyzn $(5,4 \%)$. Kobietom trudniej jest powrócić do pracy, zwłaszcza po dłuższej przerwie związanej z urlopem macierzyńskim bądź wychowawczym. W trudniejszej sytuacji są również kobiety poszukujące pracy po raz pierwszy. Analiza średniego czasu pozostawania bez pracy wskazuje na to, że kobiety pozostają w ewidencji urzędów pracy o dwa miesiące dłużej niż mężczyźni (tj. 13,7 miesiąca wobec 11,7 miesiąca) (Sytuacja kobiet $i$ mężczyzn..., 2016). Podstawowym zadaniem powiatowych urzędów pracy jest przede wszystkim pośrednictwo w znalezieniu pracy. Jednak nie jest to główna przyczyna wyrejestrowania. Bezrobotni korzystają z możliwości przejścia na rentę lub emeryturę, zasiłków przedemerytalnych, podejmują naukę w systemie dziennym. Jednym z częstszych powodów wyrejestrowań z urzędu pracy jest odmówienie bez uzasadnionej przyczyny przyjęcia propozycji odpowiedniego zatrudnienia, co skutkuje wykreśleniem takiej osoby z rejestru urzędu.

Celem artykułu jest ocena wpływu płci na prawdopodobieństwo formy wyjścia $\mathrm{z}$ bezrobocia rejestrowanego. $\mathrm{W}$ badaniu zastosowano wybrane metody analizy trwania uwzględniające obserwacje cenzurowane. Do oceny prawdopodobieństwa wyjścia z bezrobocia z określonej przyczyny wykorzystano funkcję skumulowanej częstości $(C I F)$. Różnice w przebiegu krzywych $C I F$ dla płci porównano, korzystając z testu Graya. Analizę przeprowadzono, wykorzystując dane z Powiatowego Urzędu Pracy w Szczecinie.

\section{Dane wykorzystane w badaniu}

W badaniu skorzystano z anonimowych danych indywidualnych pozyskanych z Powiatowego Urzędu Pracy w Szczecinie i wygenerowanych z systemu SYRIUSZ. Zebrano informacje dotyczące 22078 osób bezrobotnych (w tym 9770 kobiet) zarejestrowanych w 2013 roku. Zdarzeniem kończącym obserwację każdej jednostki był 
moment wyrejestrowania z urzędu z określonego powodu. Jeżeli wyrejestrowanie nie nastąpiło do końca 2014 roku, to taką obserwację przyjęto za cenzurowaną prawostronnie (1856 obserwacji, w tym 913 kobiet). Analizie podlegał czas od momentu zarejestrowania do momentu wyrejestrowania będący zmienną losową $T$. Rejestry urzędów pracy oprócz dokładnych danych o osobach bezrobotnych obejmują obecnie również kilkadziesiąt przyczyn ich wyrejestrowania. Są to między innymi powody związane z podjęciem zatrudnienia, przejściem na rentę lub emeryturę, kontynuacją nauki w systemie dziennym, wyjazdem za granicę, zmianą miejsca zamieszkania. Przyczyny te zawarto w siedmiu grupach: praca niesubsydiowana, wykreślenie, praca subsydiowana, podjęcie działalności gospodarczej, wyjazd za granicę, przejście na rentę, emeryturę lub zasiłek i pozostałe. Grupy te stanowią różne formy zdarzeń konkurujących, które poddano analizie. Szczegółowe informacje o przyczynach wyrejestrowania wchodzących w skład każdej z form wyjścia z bezrobocia wraz z liczebnościami zaprezentowano $\mathrm{w}$ tabeli 1 . W badaniu analizowano wpływ płci na prawdopodobieństwo wyrejestrowania osób bezrobotnych w zależności od ich cech: wykształcenia, wieku, liczby zarejestrowań w urzędzie oraz stażu pracy. W tabeli 2 podano sposób oznaczenia wariantów poszczególnych cech.

Tabela 1. Formy wyrejestrowania z urzędu pracy i ich liczebność

\begin{tabular}{|c|c|c|}
\hline Formy & Przyczyny szczegółowe & $\begin{array}{c}\text { Ogółem } \\
\text { (kobiety) }\end{array}$ \\
\hline 1 & 2 & 3 \\
\hline $\begin{array}{l}\text { Praca } \\
\text { niesubsydiowana }\end{array}$ & podjęcie pracy lub innego zatrudnienia & $\begin{array}{c}7807 \\
(4003)\end{array}$ \\
\hline Wykreślenie & $\begin{array}{l}\text { odmówienie przyjęcia propozycji zatrudnienia lub innej pracy zarobkowej, } \\
\text { wykonywania prac interwencyjnych, robót publicznych, udziału w szkoleniu, } \\
\text { stażu, przygotowaniu zawodowym w miejscu pracy; niestawienie się w PUP } \\
\text { w wyznaczonym terminie, nieprzedstawienie zaświadczenia o niezdolności } \\
\text { do pracy wskutek choroby, odmówienie lub przerwanie udziału w działaniach } \\
\text { w ramach Programu Aktywizacja i Integracja, brak gotowości do podjęcia } \\
\text { pracy przez okres co najmniej } 10 \text { dni, wniosek bezrobotnego o wykreślenie } \\
\text { z ewidencji }\end{array}$ & $\begin{array}{l}8965 \\
(3264)\end{array}$ \\
\hline $\begin{array}{l}\text { Praca } \\
\text { subsydiowana }\end{array}$ & $\begin{array}{l}\text { podjęcie robót publicznych, prac interwencyjnych, praca w ramach } \\
\text { utworzonego dodatkowego miejsca pracy z tytułu udzielonej pożyczki lub } \\
\text { dofinansowania wynagrodzenia za zatrudnienie bezrobotnego } 50+\end{array}$ & $929(424)$ \\
\hline $\begin{array}{l}\text { Działalność } \\
\text { gospodarcza }\end{array}$ & $\begin{array}{l}\text { podjęcie pozarolniczej działalności gospodarczej, przyznanie jednorazowo } \\
\text { środków na podjęcie działalności gospodarczej, rozpoczęcie działalności } \\
\text { gospodarczej ze środków PFRON }\end{array}$ & $897(382)$ \\
\hline Wyjazd za granicę & wyjazd za granicę na okres co najmniej 30 dni - brak gotowości & $445(201)$ \\
\hline
\end{tabular}




\begin{tabular}{|l|l|c|}
\hline \multicolumn{1}{|c|}{1} & \multicolumn{1}{|c|}{2} & \multicolumn{1}{|c|}{3} \\
\hline $\begin{array}{l}\text { Renta/emerytura/ } \\
\text { zasiłek }\end{array}$ & $\begin{array}{l}\text { nabycie prawa do emerytury, świadczenia rehabilitacyjnego, renty, pobieranie } \\
\text { zasiłku stałego, podleganie ubezpieczeniu emerytalno-rentowemu z tytułu } \\
\text { stałej pracy jako domownik w gospodarstwie rolnym, pobieranie świadczenia } \\
\text { pielęgnacyjnego, dodatku do zasiłku rodzinnego z tytułu samotnego } \\
\text { wychowywania dziecka, pobieranie zasiłku dla opiekuna, przyznanie prawa do } \\
\text { pobierania świadczenia/zasiłku przedemerytalnego }\end{array}$ & 685 (380) \\
\hline Pozostałe & $\begin{array}{l}\text { zmiana miejsca zameldowania lub pobytu poza obszar działania PUP, } \\
\text { niezdolność do pracy wskutek choroby lub przebywania w zamkniętym } \\
\text { ośrodku odwykowym, rozpoczęcie szkolenia organizowanego przez inny } \\
\text { podmiot niż PUP, zgon, powołanie do zasadniczej służby wojskowej, podjęcie } \\
\text { nauki w szkole w systemie dziennym }\end{array}$ & 494 (203) \\
\hline
\end{tabular}

Źródło: opracowanie własne.

Tabela 2. Warianty obserwowanych cech i ich oznaczenie

\begin{tabular}{|l|c|l|c|}
\hline \multicolumn{1}{|c|}{ Cecha } & Oznaczenie & \multicolumn{1}{c|}{ Cecha } & Oznaczenie \\
\hline Wykształcenie & & Wiek & $W_{1}$ \\
\hline Co najwyżej gimnazjalne & $S_{1}$ & $18-24$ & $W_{2}$ \\
\hline Zasadnicze zawodowe & $S_{2}$ & $25-34$ & $W_{3}$ \\
\hline Średnie ogólnokształcące & $S_{3}$ & $35-44$ & $W_{4}$ \\
\hline Średnie zawodowe & $S_{4}$ & $45-54$ & $W_{5}$ \\
\hline Wyższe & $S_{5}$ & $55-59$ & \\
\hline Liczba zarejestrowań & & Staż & $D_{0}$ \\
\hline Zarejestrowani po raz pierwszy & $Z_{0}$ & Bez doświadczenia zawodowego & $D_{1}$ \\
\hline Zarejestrowani po raz kolejny & $Z_{1}$ & Z doświadczeniem zawodowym & \\
\hline
\end{tabular}

Źródło: opracowanie własne.

\section{Metodyka badania}

W badaniu wykorzystano wywodzące się z demografii metody analizy trwania (przeżycia) coraz częściej stosowane do badania czasu trwania zjawisk społeczno-ekonomicznych, w tym również w badaniu bezrobocia (Bieszk-Stolorz, 2013; Bieszk-Stolorz, Markowicz, 2012; Landmesser, 2013). Przyjmuje się, że czas trwania jednostki w danym stanie aż do momentu wystąpienia określonego zdarzenia kończącego obserwację jest zmienną losową $T$. Podstawowym pojęciem jest funkcja trwania nazywana również funkcją przeżycia, zdefiniowana następująco:

$$
S(t)=P(t>T)=1-F(t)
$$

gdzie:

$T$ - czas trwania zjawiska,

$F(T)$ - dystrybuanta rozkładu zmiennej losowej $T$. 
Funkcja trwania określa prawdopodobieństwo tego, że określone zdarzenie nie zajdzie co najmniej do czasu $t$. W zależności od zdefiniowanego zdarzenia czasami wygodniej jest analizować dystrybuantę $F(T)$ wyrażającą prawdopodobieństwo zajścia zdarzenia najpóźniej do czasu $t$. Jeżeli badaniu podlega czas trwania bezrobocia, a zdarzeniem jest podjęcie pracy przez osobę bezrobotną zarejestrowaną w urzędzie, to estymator funkcji trwania informuje o tym, jakie jest prawdopodobieństwo pozostania w rejestrze, a estymator dystrybuanty pozwala określić, jakie jest prawdopodobieństwo podjęcia pracy. W tym przypadku oba estymatory są krzywymi.

Drugą funkcją w analizie trwania jest funkcja hazardu opisująca intensywność zajścia zdarzenia w momencie $t$ pod warunkiem przetrwania do czasu $t$, określona następująco:

$$
h(t)=\lim _{\Delta t \rightarrow 0} \frac{P(t \leq T<t+\Delta t \mid T \geq t)}{\Delta t} .
$$

W badaniach wyznacza się również funkcję skumulowanego hazardu, która jest sumą hazardu do czasu $t$ i dla czasu dyskretnego i jest określona wzorem:

$$
H(t)=\sum_{j: j \leq t} h\left(t_{j}\right) .
$$

Badanie związane z zastosowaniem modeli trwania polega najczęściej na obserwacji jednostek należących do zdefiniowanej kohorty. Jeżeli ustalony jest okres obserwacji, to część z jednostek może nie zaznać zdarzenia przez jego końcem i czas trwania jest znany jedynie częściowo. Obserwacje takie uznaje się za cenzurowane prawostronnie.

W analizie czasu trwania zjawisk można wyodrębnić kilka zdarzeń kończących obserwacje. Jeżeli wystąpienie każdego z nich wyklucza wystąpienie pozostałych zdarzeń lub w zasadniczy sposób zmienia prawdopodobieństwo ich wystąpienia, to mówi się o zdarzeniach konkurujących, a ryzyko ich wystąpienia nazywa ryzykiem konkurującym (Gooley, Leisenring, Crowley, Storer, 1999). W tego rodzaju badaniach przyjmuje się dwa założenia. Po pierwsze, zdarzenia są od siebie niezależne, czyli wystąpienie zdarzenia określonego typu nie ma żadnego wpływu na prawdopodobieństwo wystąpienia jakichkolwiek innych zdarzeń (Crowder, 1994, 1996, 1997). Po drugie, badana jednostka jest w tym samym czasie narażona na różne rodzaje ryzyka. Jednak zakłada się, że ewentualne zdarzenie wynika tylko z jednego z tych czynników, które nazywa się przyczyna niepowodzenia (Aly, Kochar, McKeague, 1994). W analizie trwania często stosuje się takie podejście, w którym zdarzenia 
inne niż analizowane traktuje się jako obserwacje cenzurowane. Prowadzi to do pewnych przeszacowań prawdopodobieństwa zajścia zdarzenia (Bieszk-Stolorz, 2017a). W przypadku różnych zdarzeń kończących obserwację warto wykorzystać modele oceny ryzyka zdarzeń konkurujących (Klein, Bajorunaite, 2004). Do oceny prawdopodobieństwa zajścia zdarzenia z powodu $k$ (jednego z $K$ konkurujących) przed czasem $t$ stosuje się funkcję skumulowanej częstości (Cumulative Incidence Function) $C_{1} F_{k}(t)$ określoną następująco (Klein, Moeschberger, 2003, s. 52):

$$
C I F_{k}(t)=P(t \leq T, \delta=k)=\int_{0}^{t} S(u) h_{k}(u) d u=\int_{0}^{t} S(u) d H_{k},
$$

gdzie:

$H_{k}(t)$ dla $k=1,2,3, \ldots, K$ - funkcja hazardu skumulowanego,

$S(t)$ - funkcja przeżycia,

$\delta=0$ dla obserwacji cenzurowanych oraz $\delta=1, \ldots, K$ dla obserwacji kończących się zdarzeniem typu $k$ (jednym z $K$ konkurujących).

Estymator funkcji skumulowanej częstości występowania, po raz pierwszy zaproponowany przez Kalbfleischa i Prentice’a (2002), ma postać (Marubini, Valsecchi, 1995):

$$
C \hat{I} F_{k}(t)=\sum_{j: t_{j} \leq t} \hat{S}\left(t_{j-1}\right) \frac{d_{k j}}{n_{j}} .
$$

Estymator ten jest skumulowanym prawdopodobieństwem wystąpienia zdarzenia typu $k$ przed lub w czasie $t$. Pozwala określić wzorce zajścia zdarzenia z powodu $k$ i ocenić, w jakim stopniu każdy powód przyczynia się do całkowitej porażki. W badaniach stosuje się również inne estymatory prawdopodobieństwa zajścia zdarzeń konkurujących (Bieszk-Stolorz, 2017b).

Ponieważ $\sum_{k=1}^{K} d_{k j}=d_{j}$, to prawdziwa jest zależność:

$$
\sum_{k=1}^{K} C \hat{I} F_{k}(t)=1-\hat{S}(t)
$$

W szczególnym przypadku, jeżeli nie ma zdarzeń konkurujących, to zachodzi równość:

$$
C \hat{I F}(t)=1-\hat{S}(t)
$$

Wówczas estymator funkcji skumulowanej częstości pokrywa się z estymatorem dystrybuanty. 
Dla zdarzeń konkurujących równość funkcji skumulowanych częstości dla $n$ od grup weryfikuje się, wykorzystując test Graya (1988). Test ten porównuje średnie ważone hazardów skumulowanej funkcji częstości. Dla dwóch porównywanych podgrup A i B oraz $k$-tego rodzaju ryzyka ma on postać:

$$
\int_{0}^{\infty} W(u)\left(\hat{f}_{k}^{\mathrm{A}}(u) /\left(1-C \hat{I} F_{k}^{\mathrm{A}}(u)\right)-\hat{f}_{k}^{\mathrm{B}}(u) /\left(1-C \hat{I} F_{k}^{\mathrm{B}}(u)\right)\right) \mathrm{d} u,
$$

gdzie:

$W(u)$ - funkcja wagi,

$\hat{f}_{k}^{\mathrm{A}}, \hat{f}_{k}^{\mathrm{B}}-$ estymatory funkcji gęstości,

$C \hat{I} F_{k}^{\mathrm{A}}, C \hat{I} F_{k}^{\mathrm{B}}$ - estymatory funkcji skumulowanych częstości odpowiednio dla podgrup A i B.

Hipoteza zerowa zakłada brak różnic między funkcjami skumulowanych częstości wyznaczonymi dla podgrup. Dla $k$-tego ryzyka konkurującego i dwóch podgrup A i B wyraża się ona wzorem:

$$
\begin{aligned}
& H_{0}: C I F_{k}^{\mathrm{A}}(t)=C I F_{k}^{\mathrm{B}}(t) \text { dla } t \leq T ; \\
& H_{A}: C I F_{k}^{\mathrm{A}}(t) \neq C I F_{k}^{\mathrm{B}}(t) \text { dla pewnego } t .
\end{aligned}
$$

Statystyka testowa ma rozkład chi-kwadrat o $n-1$ stopniach swobody. W przypadku braku występowania zdarzeń konkurujących test Graya sprowadza się do zwykłego testu log-rank.

\section{Wyniki badania wpływu płci na formę wyjścia z bezrobocia}

Analiza przebiegała w dwóch etapach. Pierwszy z nich polegał na wykorzystaniu skumulowanej funkcji częstości $(C I F)$ do oceny prawdopodobieństwa różnych form wyjścia z bezrobocia kobiet i mężczyzn (rys. 1-2). Przebieg tych funkcji wskazuje na to, że najbardziej prawdopodobnymi przyczynami wyrejestrowania osób bezrobotnych $\mathrm{w}$ analizowanym okresie było podjęcie pracy niesubsydiowanej oraz wykreślenie z rejestru, przy czym pierwsza forma była dominująca dla kobiet, a druga w przypadku mężczyzn. Prawdopodobieństwa podjęcia pracy subsydiowanej, działalności gospodarczej, wyjazdu za granicę, przejścia na rentę, emeryturę lub zasiłek oraz pozostałe formy miały znaczenie marginalne i nie przekroczyły wartości 0,05 .

Estymowane funkcje trwania dla powodu „wykreślenie” i „renta/emerytura/ zasiłek" zarówno dla kobiet, jak i dla mężczyzn charakteryzują się nieregularną 
krzywizną. Dla zdarzenia „wykreślenie” znaczny skok w pierwszym miesiącu był związany ze zwiększoną liczbą wyrejestrowań z powodu niestawiennictwa osoby bezrobotnej w PUP w wyznaczonym terminie. W przypadku „renty/emerytury/ zasiłku" skok wartości w siódmym miesiącu od zarejestrowania spowodowany był zwiększoną liczbą wyrejestrowań z powodu przyznania prawa do pobierania świadczenia/zasiłku przedemerytalnego. Suma estymatorów $C_{k} F_{k}$ dla wszystkich form wyrejestrowania jest mniejsza od 1. Jest to spowodowane istnieniem obserwacji cenzurowanych. Nie wszystkie osoby zostały wyrejestrowane z urzędu do końca 2014 roku. Niezerowa różnica, która powstała, pozwala określić prawdopodobieństwo pozostania w rejestrze bezrobotnych po 24 miesiącach od momentu zarejestrowania. W przypadku kobiet było ono równe 0,05 , a dla mężczyzn 0,04 .

Rysunek 1. Prawdopodobieństwo wyrejestrowania kobiet

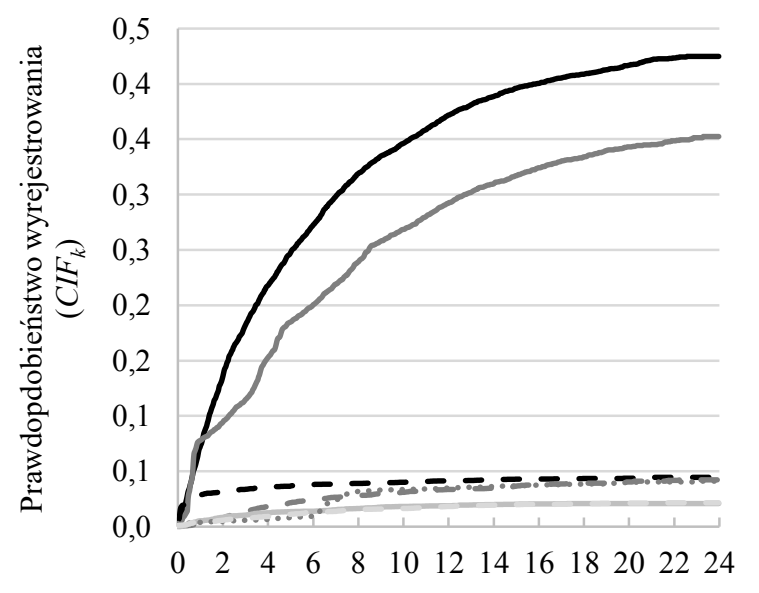

- praca niesubsydiowana

— wykreślenie

- - praca subsydiowana

- - - działalność gospodarcza

wyjazd za granicę

........ renta/emerytura/zasiłek

Czas (miesiące)

Źródło: opracowanie własne. 
Rysunek 2. Prawdopodobieństwo wyrejestrowania mężczyzn
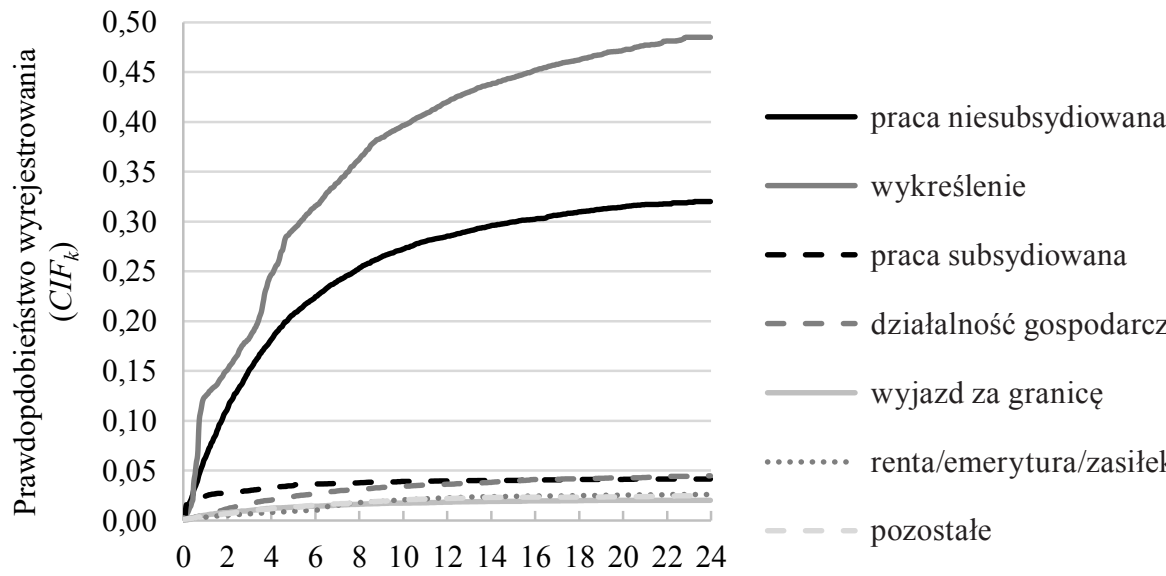

— wykreślenie

- - praca subsydiowana

- - - działalność gospodarcza

wyjazd za granicę renta/emerytura/zasiłek

pozostałe

Czas (miesiące)

Źródło: opracowanie własne.

Prawdopodobieństwo różnych form wyjścia z bezrobocia kobiet i mężczyzn analizowano również w podgrupach wyodrębnionych ze względu na: wykształcenie, wiek, liczbę zarejestrowań i posiadany staż pracy. Drugi etap badania polegał na ocenie wpływu płci na formę wyjścia z bezrobocia z wykorzystaniem testu Graya (tab. 3). Przyjęto poziom istotności $p=0,05$. Brak podstaw do odrzucenia hipotezy zerowej świadczy o braku istotnych różnic w przebiegu krzywych $C I F_{k}$, czyli o braku wpływu płci na prawdopodobieństwo określonej formy wyrejestrowania. Test Graya umożliwia wykrycie różnic w przebiegu krzywych, lecz nie pozwala na określenie wzajemnego ich położenia. W tym celu należy analizować wartości estymatorów $C I F_{k}$, korzystając z ich wykresów. Wyniki takiej analizy przedstawiono w tabeli 4.

Wpływ płci był najsilniejszy w przypadku pracy niesubsydiowanej (przeważały kobiety), wykreślenia (przeważali mężczyźni) i przejścia na rentę, emeryturę lub zasiłek (od siódmego miesiąca przeważały kobiety). W przypadku podjęcia pracy niesubsydiowanej wyjątek stanowili mężczyźni w wieku 55-59 lat. Dla kobiet jest to wiek przedemerytalny, co może sugerować, że większość z nich korzystała z zasiłku przedemerytalnego. Prawdopodobieństwo podjęcia pracy subsydiowanej było istotnie większe dla kobiet z wykształceniem ogólnokształcącym i wyższym oraz w grupach wieku 18-24 i 25-34 lata. Podjęcie działalności gospodarczej było najbardziej prawdopodobne w przypadku mężczyzn z wykształceniem co najwyżej 
gimnazjalnym, ogólnokształcącym i wyższym oraz w wieku 45-54 lata. Z pozostałych form wyjścia z bezrobocia najczęściej korzystali mężczyźni z wykształceniem co najwyżej gimnazjalnym, w grupie wieku 45-54 lata oraz po raz kolejny zarejestrowani w urzędzie pracy. Najmniejszy wpływ płci był na wyrejestrowanie z powodu wyjazdu za granicę. $\mathrm{W}$ tym przypadku przeważali jedynie mężczyźni z wykształceniem wyższym.

Tabela 3. Wyniki testu Graya

\begin{tabular}{|c|c|c|c|c|c|c|c|}
\hline Cecha & 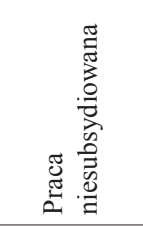 & 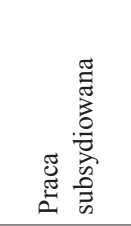 & 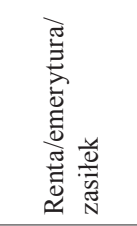 & 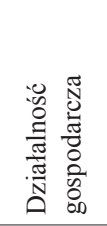 & 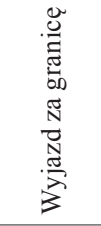 & 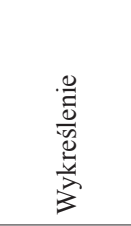 & 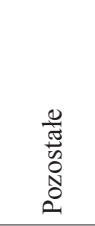 \\
\hline$S_{1}$ & $\begin{array}{c}26,691 \\
(<0,0001)\end{array}$ & $\begin{array}{c}0,024 \\
(0,876)\end{array}$ & $\begin{array}{l}13,217 \\
(0,000)\end{array}$ & $\begin{array}{l}12,294 \\
(0,000)\end{array}$ & $\begin{array}{c}1,633 \\
(0,201)\end{array}$ & $\begin{array}{c}70,717 \\
(<0,0001)\end{array}$ & $\begin{array}{c}7,090 \\
(0,008)\end{array}$ \\
\hline$S_{2}$ & $\begin{array}{l}14,049 \\
(0,000)\end{array}$ & $\begin{array}{c}0,104 \\
(0,747) \\
\end{array}$ & $\begin{array}{c}19,691 \\
(<0,0001)\end{array}$ & $\begin{array}{c}2,786 \\
(0,095) \\
\end{array}$ & $\begin{array}{c}0,586 \\
(0,444) \\
\end{array}$ & $\begin{array}{c}29,127 \\
(<0,0001)\end{array}$ & $\begin{array}{c}1,472 \\
(0,225)\end{array}$ \\
\hline$S_{3}$ & $\begin{array}{c}0,519 \\
(0,471)\end{array}$ & $\begin{array}{c}6,859 \\
(0,009)\end{array}$ & $\begin{array}{c}28,420 \\
(<0,0001)\end{array}$ & $\begin{array}{c}4,494 \\
(0,034)\end{array}$ & $\begin{array}{c}0,469 \\
(0,493)\end{array}$ & $\begin{array}{c}17,944 \\
(<0,0001)\end{array}$ & $\begin{array}{c}3,416 \\
(0,065)\end{array}$ \\
\hline$S_{4}$ & $\begin{array}{c}15,922 \\
(<0,0001)\end{array}$ & $\begin{array}{c}2,099 \\
(0,147) \\
\end{array}$ & $\begin{array}{c}21,194 \\
(<0,0001)\end{array}$ & $\begin{array}{c}2,240 \\
(0,135) \\
\end{array}$ & $\begin{array}{c}2,400 \\
(0,121) \\
\end{array}$ & $\begin{array}{c}78,328 \\
(<0,0001)\end{array}$ & $\begin{array}{c}1,474 \\
(0,225) \\
\end{array}$ \\
\hline$S_{5}$ & $\begin{array}{c}27,284 \\
(<0,0001)\end{array}$ & $\begin{array}{c}25,318 \\
(<0,0001)\end{array}$ & $\begin{array}{c}0,609 \\
(0,435)\end{array}$ & $\begin{array}{l}12,848 \\
(0,000) \\
\end{array}$ & $\begin{array}{c}9,704 \\
(0,002)\end{array}$ & $\begin{array}{c}42,588 \\
(<0,0001)\end{array}$ & $\begin{array}{c}1,334 \\
(0,248)\end{array}$ \\
\hline$W_{1}$ & $\begin{array}{c}51,078 \\
(<0,0001)\end{array}$ & $\begin{array}{l}10,522 \\
(0,001)\end{array}$ & $\begin{array}{c}0,810 \\
(0,368)\end{array}$ & $\begin{array}{c}0,080 \\
(0,778)\end{array}$ & $\begin{array}{c}0,015 \\
(0,902) \\
\end{array}$ & $\begin{array}{c}125,717 \\
(<0,0001)\end{array}$ & $\begin{array}{c}0,023 \\
(0,879) \\
\end{array}$ \\
\hline$W_{2}$ & $\begin{array}{c}99,325 \\
(<0,0001)\end{array}$ & $\begin{array}{c}7,833 \\
(0,005) \\
\end{array}$ & $\begin{array}{c}4,948 \\
(0,026)\end{array}$ & $\begin{array}{c}0,281 \\
(0,596)\end{array}$ & $\begin{array}{c}0,010 \\
(0,919) \\
\end{array}$ & $\begin{array}{c}230,865 \\
(<0,0001)\end{array}$ & $\begin{array}{c}1,229 \\
(0,268)\end{array}$ \\
\hline$W_{3}$ & $\begin{array}{c}75,836 \\
(<0,0001)\end{array}$ & $\begin{array}{c}0,905 \\
(0,341)\end{array}$ & $\begin{array}{c}0,753 \\
(0,386)\end{array}$ & $\begin{array}{c}1,063 \\
(0,303) \\
\end{array}$ & $\begin{array}{c}1,078 \\
(0,299)\end{array}$ & $\begin{array}{c}109,771 \\
(<0,0001)\end{array}$ & $\begin{array}{c}3,086 \\
(0,079) \\
\end{array}$ \\
\hline$W_{4}$ & $\begin{array}{c}18,464 \\
(<0,0001)\end{array}$ & $\begin{array}{c}0,079 \\
(0,778) \\
\end{array}$ & $\begin{array}{l}13,627 \\
(0,000) \\
\end{array}$ & $\begin{array}{c}4,034 \\
(0,045) \\
\end{array}$ & $\begin{array}{c}1,141 \\
(0,285) \\
\end{array}$ & $\begin{array}{c}30,944 \\
(<0,0001)\end{array}$ & $\begin{array}{c}4,346 \\
(0,037) \\
\end{array}$ \\
\hline$W_{5}$ & $\begin{array}{c}18,880 \\
(<0,0001)\end{array}$ & $\begin{array}{c}1,900 \\
(0,168)\end{array}$ & $\begin{array}{c}171,609 \\
(<0,0001)\end{array}$ & $\begin{array}{c}1,296 \\
(0,255)\end{array}$ & $\begin{array}{c}0,150 \\
(0,699)\end{array}$ & $\begin{array}{c}19,484 \\
(<0,0001)\end{array}$ & $\begin{array}{c}2,189 \\
(0,139)\end{array}$ \\
\hline$Z_{0}$ & $\begin{array}{c}58,372 \\
(<0,0001)\end{array}$ & $\begin{array}{c}3,436 \\
(0,064)\end{array}$ & $\begin{array}{c}8,810 \\
(0,003)\end{array}$ & $\begin{array}{c}1,055 \\
(0,304)\end{array}$ & $\begin{array}{c}0,290 \\
(0,590)\end{array}$ & $\begin{array}{c}121,741 \\
(<0,0001)\end{array}$ & $\begin{array}{c}0,490 \\
(0,484)\end{array}$ \\
\hline$Z_{1}$ & $\begin{array}{c}152,446 \\
(<0,0001)\end{array}$ & $\begin{array}{c}1,058 \\
(0,304)\end{array}$ & $\begin{array}{c}22,710 \\
(<0,0001)\end{array}$ & $\begin{array}{c}1,441 \\
(0,230)\end{array}$ & $\begin{array}{c}0,725 \\
(0,395) \\
\end{array}$ & $\begin{array}{c}284,377 \\
(<0,0001)\end{array}$ & $\begin{array}{c}7,289 \\
(0,007) \\
\end{array}$ \\
\hline$D_{0}$ & $\begin{array}{c}101,798 \\
(<0,0001)\end{array}$ & $\begin{array}{c}0,748 \\
(0,387)\end{array}$ & $\begin{array}{c}0,069 \\
(0,792) \\
\end{array}$ & $\begin{array}{c}0,002 \\
(0,960)\end{array}$ & $\begin{array}{c}0,181 \\
(0,671)\end{array}$ & $\begin{array}{c}149,236 \\
(<0,0001)\end{array}$ & $\begin{array}{c}0,084 \\
(0,772)\end{array}$ \\
\hline$D_{1}$ & $\begin{array}{c}102,029 \\
(<0,0001)\end{array}$ & $\begin{array}{c}0,156 \\
(0,693)\end{array}$ & $\begin{array}{c}32,263 \\
(<0,0001)\end{array}$ & $\begin{array}{c}1,750 \\
(0,186)\end{array}$ & $\begin{array}{c}0,047 \\
(0,829) \\
\end{array}$ & $\begin{array}{c}225,092 \\
(<0,0001)\end{array}$ & $\begin{array}{c}3,564 \\
(0,059) \\
\end{array}$ \\
\hline
\end{tabular}

Źródło: opracowanie własne. 
Tabela 4. Wpływ płci na prawdopodobieństwo wyjścia z bezrobocia (warianty istotne statystycznie)

\begin{tabular}{|c|c|c|c|c|c|c|c|}
\hline Cecha & 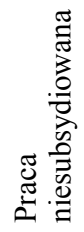 & 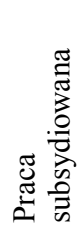 & 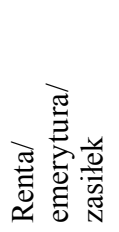 & 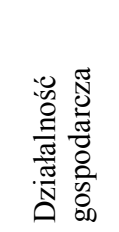 & 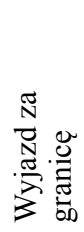 & $\begin{array}{l}\frac{0}{3} \\
\frac{0}{0.0} \\
\frac{0}{0} \\
\frac{3}{3}\end{array}$ & 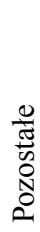 \\
\hline$S_{1}$ & K & & K & $\mathrm{M}$ & & $\mathrm{M}$ & $\mathrm{M}$ \\
\hline$S_{2}$ & $\mathrm{~K}$ & & $\mathrm{~K}>6 \mathrm{~m}$ & & & $\mathrm{M}$ & \\
\hline$S_{3}$ & & $\mathrm{~K}$ & $\mathrm{~K}$ & $M>2 m$ & & $\mathrm{M}$ & \\
\hline$S_{4}$ & $\mathrm{~K}$ & & $\mathrm{~K}>6 \mathrm{~m}$ & & & $\mathrm{M}$ & \\
\hline$S_{5}$ & K & K & & M & $\mathrm{M}$ & $\mathrm{M}$ & \\
\hline$W_{1}$ & $\mathrm{~K}$ & K & & & & $\mathrm{M}$ & \\
\hline$W_{2}$ & $\mathrm{~K}$ & $\mathrm{~K}$ & $\mathrm{~K}>6 \mathrm{~m}$ & & & $\mathrm{M}$ & \\
\hline$W_{3}$ & $\mathrm{~K}$ & & & & & $\mathrm{M}$ & \\
\hline$W_{4}$ & K & & $\mathrm{K}>6 \mathrm{~m}$ & M & & $\mathrm{M}$ & $\mathrm{M}$ \\
\hline$W_{5}$ & $\mathrm{M}$ & & $\mathrm{K}>6 \mathrm{~m}$ & & & $\mathrm{M}$ & \\
\hline$Z_{0}$ & $\mathrm{~K}$ & & $\mathrm{~K}>6 \mathrm{~m}$ & & & $\mathrm{M}$ & \\
\hline$Z_{1}$ & $\mathrm{~K}$ & & $\mathrm{~K}>6 \mathrm{~m}$ & & & $\mathrm{M}$ & $\mathrm{M}$ \\
\hline$D_{0}$ & K & & & & & $\mathrm{M}$ & \\
\hline$D_{1}$ & $\mathrm{~K}$ & & $\mathrm{~K}>6 \mathrm{~m}$ & & & $\mathrm{M}$ & \\
\hline
\end{tabular}

$\mathrm{K}$ - kobiety, M - mężczyźni, $\mathrm{K}>6 \mathrm{~m}$ - przewaga kobiet po 6 miesiącach od momentu zarejestrowania, $M>2 \mathrm{~m}$ - przewaga mężczyzn po 2 miesiącach od momentu zarejestrowania.

Źródło: opracowanie własne.

\section{Podsumowanie}

Przeprowadzone badanie wykazało, że chęć podjęcia zatrudnienia nie była jedyną przyczyną zarejestrowania się w urzędzie pracy. Bezrobotni chętnie korzystali również z innych form wychodzenia $\mathrm{z}$ bezrobocia. Prawdopodobieństwo wyrejestrowania z przyczyn innych niż podjęcie pracy było $\mathrm{w}$ analizowanym okresie zróżnicowane ze względu na płeć osoby bezrobotnej. Szczególnie mocno płeć determinowała podejmowanie pracy niesubsydiowanej (głównie kobiety) oraz wykreślenie z rejestru (głównie mężczyźni). Różnice były zauważalne także w grupach wyodrębnionych ze względu na cechy zarejestrowanych bezrobotnych, takie jak: wykształcenie, wiek, liczba zarejestrowań oraz staż pracy. W największym stopniu płeć różnicowała bezrobotnych z wykształceniem co najwyżej gimnazjalnym lub wyższym oraz w wieku 45-54 lat, w najmniejszym - w wieku 35-44 lat oraz bez doświadczenia zawodowego. 


\section{Literatura}

Aly, E.A.A., Kochar, S., McKeague, E. (1994). Some Tests for Comparing Cumulative Incidence Functions and Cause-Specific Hazard Rates. Journal of the American Statistical Association, 89 (427), 994-999. DOI: 10.1080/01621459.1994.10476833.

Bieszk-Stolorz, B. (2013). Analiza historii zdarzeń w badaniu bezrobocia. Szczecin: Volumina.pl.

Bieszk-Stolorz, B. (2017a). Cumulative Incidence Function in Studies on the Duration of the Unemployment Exit Process. Folia Oeconomica Stetinensia, 17 (1), 138-150. DOI:10.1515/foli-2017-0011.

Bieszk-Stolorz, B. (2017b). Zastosowanie metod analizy trwania w badaniu form wychodzenia z bezrobocia. Wiadomości Statystyczne, 8, 5-18.

Bieszk-Stolorz, B., Markowicz, I. (2012). Modele regresji Coxa w analizie bezrobocia. Warszawa: CeDeWu.

Bieszk-Stolorz, B., Markowicz, I. (2013). Płeć jako determinanta szansy podjęcia zatrudnienia i ryzyka rezygnacji z pośrednictwa urzędu pracy. Optimum. Studia Ekonomiczne, $6(66), 20-30$.

Crowder, M. (1994). Identifiability Crises in Competing Risks. International Statistical Review, 62 (3), 379-391. DOI: 10.2307/1403768.

Crowder, M. (1996). On Assessing Independence of Competing Risks when Failure Times are Discrete. Lifetime Data Analysis, 2 (2), 195-209. DOI: 10.1007/BF00128575.

Crowder, M. (1997). A Test for Independence of Competing Risks with Discrete Failure Times. Lifetime Data Analysis, 3 (3), 215-223. DOI: 10.1023/A:1009696830515.

Gooley, T.A., Leisenring, W., Crowley, J., Storer, B.E. (1999). Estimation of Failure Probabilities in the Presence of Competing Risks: New Representations of Old Estimators. Statistics in Medicine, 18 (6), 695-706. DOI: 10.1002/(SICI)10970258(19990330)18:6<695::AID-SIM60>3.0.CO;2-O.

Gray, R.J. (1988). A Class of K-Sample Tests for Comparing the Cumulative Incidence of a Competing Risk. The Annals of Statistics, 16 (3), 1141-1154.

Kalbfleisch, J.D., Prentice, R.L. (2002). The Statistical Analysis of Failure Time Data, Second Edition. Hoboken, New Jersey: John Wiley \& Sons.

Klein, J.P., Bajorunaite, R. (2004). Inference for Competing Risks. W: N. Balakrishnan, C.R. Rao (red.), Handbook of Statistics: Advances in Survival Analysis (s. 291-311). Vol. 23. Amsterdam: Elsevier.

Klein, J.P., Moeschberger, M.L. (2003). Survival Analysis: Techniques for Censored and Truncated Data. Second Edition. New York: Springer-Verlag.

Kotowska, I.E. (red.) (2009). Strukturalne i kulturowe uwarunkowania aktywności zawodowej kobiet $w$ Polsce. Warszawa: Scholar.

Landmesser, J. (2013). Wykorzystanie metod analizy czasu trwania do badania aktywności ekonomicznej ludności w Polsce. Warszawa: Wyd. SGGW. 
Marubini, E., Valsecchi, M. (1995). Analysing Survival Data from Clinical Trials and Observational Studies. New York: John Wiley\& Sons.

Matuszewska-Janica, A., Hozer-Koćmiel, M. (2015). Struktura zatrudnienia oraz wynagrodzenia kobiet i mężczyzn a przedmiotowa struktura gospodarcza w państwach UE. Prace Naukowe Uniwersytetu Ekonomicznego we Wrocławiu, 385, 178-186. DOI: 10.15611/pn.2015.385.19.

Sytuacja kobiet i mężczyzn na rynku pracy w 2016 roku (2017). Pobrane z: http://www. mpips.gov.pl/analizy-i-raporty/raporty-sprawozdania/rynek-pracy/ (15.09.2017).

\title{
APPLICATION OF THE GRAY TEST TO THE ASSESSMENT OF THE INFLUENCE OF GENDER ON THE FORM OF THE UNEMPLOYMENT EXIT
}

\begin{abstract}
The goal of the article is the assessment of the influence of gender on the probability of deregistration from the labour office because of accepting the unsubsidised job, subsidised job, starting the economic activity, going abroad, receiving invalidity pension, becoming retired, receiving benefitsand other causes. These forms of the unemployment exit are the various competing risks. Methods of the survival analysis taking censored observation were used in the research. The cumulative incidence function was used for the assessment of the competing risks. It enabled the assessment of the probability of the form of the unemployment exit. The Gray test was used for the analysis of differences of the influence of gender on the probability of deregistration because of the specific reason. These differences were analysed in subgroups that were extracted because of the features of the unemployed persons: education, age, the number of subsequent registrations and seniority. The analysis was conducted on the basis of the individual data of thepersons registered in the Poviat Labour Office in Szczecin.
\end{abstract}

Translated by Krzysztof Dmytrów

Keywords: survival analysis, cumulative incidence function, Gray's test, unemployment, gender JEL Codes: C41, J64 